REPORTS OF MORPHOLOGY
$\begin{gathered}\text { Official Journal of the Scientific Society of Anatomists, } \\ \text { Histologists, Embryologists and Topographic Anatomists } \\ \text { of Ukraine } \\ \text { journal homepage: https://morphology-journal.com }\end{gathered}$

\title{
Structural changes of the spleen in experimental obesity
}

Harapko T.V.

Uzhhorod National University, Medical Faculty, Uzhhorod, Ukraine

\section{ARTICLE INFO}

Received: 19 February, 2019

Accepted: 20 March, 2019

UDC: $611.41 .018: 616-056.257-092.9$

\section{CORRESPONDING AUTHOR}

e-mail: garapkotv@gmail.com Harapko T.V.

\begin{abstract}
The paper presents and analyzes data from an experimental study conducted on white rats in females and males of reproductive age. Obesity is one of the leading causes of premature death worldwide. The purpose of the research is to establish the morphometric and histological changes of the rat spleen parenchyma in experimental obesity and after the abolition of the high-calorie diet (HCD). We conducted a study on 70 white rats of reproductive age (2.5-6.5 months) weighing 120-280 g. High-calorie diet was achieved due to the fact that food was added sodium glutamate at a dose of $67 \mathrm{mg} / \mathrm{kg}$ of body weight of the rat. Controls were 10 white rats that received a standard vivarium diet instead of a high-calorie diet. Statistical processing of digital data was performed using Excel software and STATISTICA 6.0 using the parametric methods. Eight weeks after HCD, there was a significant decrease in the relative area of white pulp in the spleen parenchyma of white rats in males and females by $16.2 \%$ and $17.4 \%$, respectively, and an increase in the relative area of red pulp by $5.6 \%$ and $6.2 \%$, respectively. There is an immuno-inducing effect with enhanced proliferation of activated lymphocytes and their subsequent differentiation into plasma cells. Eight weeks after the abolition of $H C D$, the relative area of white pulp in the spleen parenchyma of white rats in males and females was $16.8 \%$ and $16.9 \%$ less than the parameters of the intact group of animals. Accordingly, the relative area of the red pulp by $5.8 \%$ and $6.1 \%$ exceeds the parameters of the intact group of animals. The area of the lymph nodes and the size of their reproductive centers decrease. The number of monocytes, macrophages and plasmocytes increases in the organ parenchyma. Hemosiderin residues occur both in the cytoplasm of macrophages and in intercellular spaces. Arteries with thickened wall, full-blooded, veins enlarged and fullblooded. The venous sinuses of the red pulp are dilated to contain hemosiderin residues. Thus, the depletion of lymphoid tissue with progression of mainly white pulp atrophy has been established. In the conditions of the eight-week abrogation of the HCD, no reverse changes in the structure of the parenchyma of the spleen were detected.

Keywords: obesity, rat, spleen, white pulp, red pulp.
\end{abstract}

\section{Introduction}

Obesity is one of the leading causes of premature death worldwide [5]. This is due to the fact that obesity increases the risk of cardiovascular disease (coronary heart disease, congestive heart failure, hypertension) [1, 11, 21], type II diabetes [10,17], obstructive sleep apnea syndrome, neuropathy [6], osteoarthritis, dementia, splenomegaly [4, 8], fatty liver disease [19], and others [12, 16]. Obesity is also associated with a wide range of cancers (colon, breast, endometrium, kidney, esophagus, stomach, pancreas, and gall bladder), and along with insulin resistance (IR) is a risk factor for developing hepatocellular carcinoma [14, 17]. In chronic diseases, obesity as a concomitant pathology complicates the course of the underlying disease $[5,16$, $22,23]$.
In the current scientific literature there is not enough information about the effect of obesity on the immune (lymphoid) organs, which provide protection of the body against foreign antigens. Adipose tissue is a complex endocrine organ whose effect on organs and tissues is significant and diverse, increasing the likelihood of multiple diseases $[9,15,18,20]$. Investigations into the dynamics of changes in the structural organization of organs and tissues, as well as possible methods for their correction, remain relevant and important for both theoretical and practical medicine.

Aim of the study: to study the morphometric and histological changes of the rat spleen parenchyma in experimental obesity and after abolition of the high-calorie 
diet.

\section{Materials and methods}

This study is part of the complex theme "Structural organization, angioarchitectonics and anthropometric features of organs in the intra- and extracorporeal periods of development, under the influence of exogenous and endogenous factors" - state registration number $0115 \mathrm{U} 000041$.

The study was performed on 70 white rats of reproductive age (2.5-6.5 months) weighing 120-280 g.

Microanatomy of the structural components of the white rat's spleen under physiological norms was examined in 10 intact animals (first group). The experimental animals were divided into 5 groups: a second group of animals (10 rats) fed a high-calorie diet (HCD) for 8 weeks; a third group of animals ( 10 rats) fed HCD for 8 weeks, followed by 2 weeks of withdrawal (standard vivarium diet); a fourth group of animals ( 10 rats) fed HCD for 8 weeks followed by 4 weeks of withdrawal; 5 group of animals (10 rats) fed HCD for 8 weeks followed by 6 weeks of withdrawal; 6 group of animals (10 rats) that were fed HCD for 8 weeks, followed by 8 weeks of withdrawal. Each group had 5 male rats and 5 female rats. HCD was achieved due to the fact that glutamate sodium was added to food at a dose of $67 \mathrm{mg} /$ $\mathrm{kg}$ of body weight of the rat. Controls were 10 white rats that received a standard vivarium diet instead of a high-calorie diet.

All experimental animals were kept in the vivarium of Danylo Halytsky Lviv National Medical University. The studies were conducted in accordance with the provisions of the "European Convention for the Protection of Vertebrate Animals Used for Experimental and Other Scientific Purposes" (Strasbourg, 1986), Council of Europe Directive 86/609/EEC (1986), Law of Ukraine No. 3447-IV "On the protection of animals against abuse", the general ethical principles of animal experimentation, approved by the First National Congress of Ukraine on Bioethics (2001).

Morphometric studies were performed using a system of visual analysis of histological preparations. The studies were performed at certain times of the experiment in samples stained with hematoxylin and eosin. Images from histological specimens of the spleen were taken to a computer monitor using a MICROmed SEO SSCAN by microscope and using a Vision CCD Camera. Morphometric studies were performed using VideoTest5.0, KAAPA Image Base, Stepanizer and Microsoft Excel on a personal computer.

Statistical processing of digital data was performed using "Excel" and "STATISTICA 6.0" software using parametric methods. The numerical values of the parameters are represented by sample averages (M), standard deviation $(\sigma)$, standard error of the mean $(m)$, Student's $t$ test $(t)$. The results of the calculations were presented in graph form in histograms using Microsoft Office, with confidence intervals.

\section{Results}

The spleen belongs to the secondary lymphoid organs, in which there is antigen-dependent proliferation and differentiation of $T$ and $B$ lymphocytes. The histological structure of the spleen of intact animals corresponds to the species norm. Outside, the organ is surrounded by a capsule from which the lugs depart. The spleen is consisting of red and white pulp. The red pulp contains blood cells surrounded by reticular cells. The white pulp consists of splenic lymph nodes and surrounding arteriolar lymphoid vagina (Fig. 1).

After 8 weeks of HCD, a significant decrease in the relative area of white pulp in the spleen parenchyma of white rats of males and females was observed to $21.59 \pm 1.22 \%$ and $21.78 \pm 1.31 \%$, which is $16.2 \%$ and $17.4 \%$ less than the parameters of the intact group of animals (Table 1). Accordingly, the relative area of the red pulp increases to $78.41 \pm 1.45 \%$ in male rats and to $78.22 \pm 1.54 \%$ in female rats. These figures are $5.6 \%$ and $6.2 \%$ higher than the parameters of the intact group of animals (see Table 1).

After 8 weeks of high-calorie diet (second group of animals) in both male and female rats, the number of monocytes, macrophages and plasmocytes increased. Hemosiderin residues occur both in the cytoplasm of macrophages and in intercellular spaces (Fig. 2). The presence of iron-containing pigment is evidence of erythrocyte death. The proportion of reticular connective tissue in Billroth cords is increasing. The veins of the red pulp are full-blooded. There is an immuno-inducing effect with enhanced proliferation of activated lymphocytes and their subsequent differentiation into plasma cells. Around small vessels, eosinophilic aggregation and lipid accumulation in the enlarged sinuses are found.

At 2 weeks after the abolition of HCD (third group of animals), the relative area of white pulp in the spleen

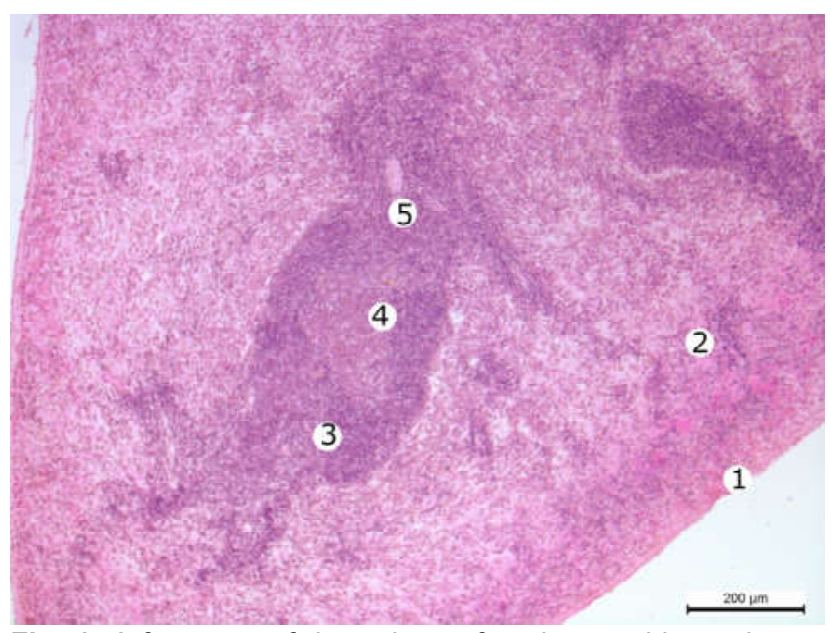

Fig. 1. A fragment of the spleen of an intact white male rat. Hematoxylin-eosin. Objective lens $\times 10$, eyepiece $\times 10.1$ - capsule; 2 - red pulp; 3 - white pulp; 4 - center of reproduction of the lymph node; 5 - central artery. 
Table 1. Dynamics of changes of relative areas (\%) of red and white pulp of spleen of white rats of control and experimental groups $(\mathrm{M} \pm \mathrm{m})$.

\begin{tabular}{|l|c|c|c|c|}
\hline \multirow{2}{*}{ Group of animals } & \multicolumn{2}{c|}{ Male rats } & \multicolumn{2}{c|}{ Female rats } \\
\cline { 2 - 5 } & $\mathrm{S}_{\text {white pulp }}$ & $\mathrm{S}_{\text {red pulp }}$ & $\mathrm{S}_{\text {white pup }}$ & $\mathrm{S}_{\text {red pulp }}$ \\
\hline Group 1 - intact animals & $25.78 \pm 1.18$ & $74.22 \pm 1.33$ & $26.38 \pm 1.02$ & $73.62 \pm 1.42$ \\
\hline Group 2 - 8 weeks of HCD & $21.59 \pm 1.22^{*}$ & $78.41 \pm 1.45^{*}$ & $21.78 \pm 1.31^{*}$ & $78.22 \pm 1.54^{*}$ \\
\hline Group 3 - 8 weeks of HCD, 2 weeks of discontinuation & $21.65 \pm 1.43^{*}$ & $78.35 \pm 1.87^{*}$ & $21.53 \pm 1.21^{*}$ & $78.47 \pm 1.65^{*}$ \\
\hline Group 4 - 8 weeks of HCD, 4 weeks of discontinuation & $21.51 \pm 1.09^{*}$ & $78.49 \pm 1.56^{*}$ & $21.19 \pm 0.69^{*}$ & $78.81 \pm 1.23^{*}$ \\
\hline Group 5 - 8 weeks of HCD, 6 weeks of discontinuation & $21.53 \pm 1.03^{*}$ & $78.47 \pm 1.34^{*}$ & $21.88 \pm 0.98^{*}$ & $78.12 \pm 1.76^{*}$ \\
\hline Group 6 - 8 weeks of HCD, 8 weeks of discontinuation & $21.46 \pm 1.05^{*}$ & $78.54 \pm 1.54^{*}$ & $21.91 \pm 1.23^{*}$ & $78.09 \pm 1.43^{*}$ \\
\hline
\end{tabular}

Note: ${ }^{*}$ - values that are statistically significantly different from those of the intact animal group $(p<0.05)$.

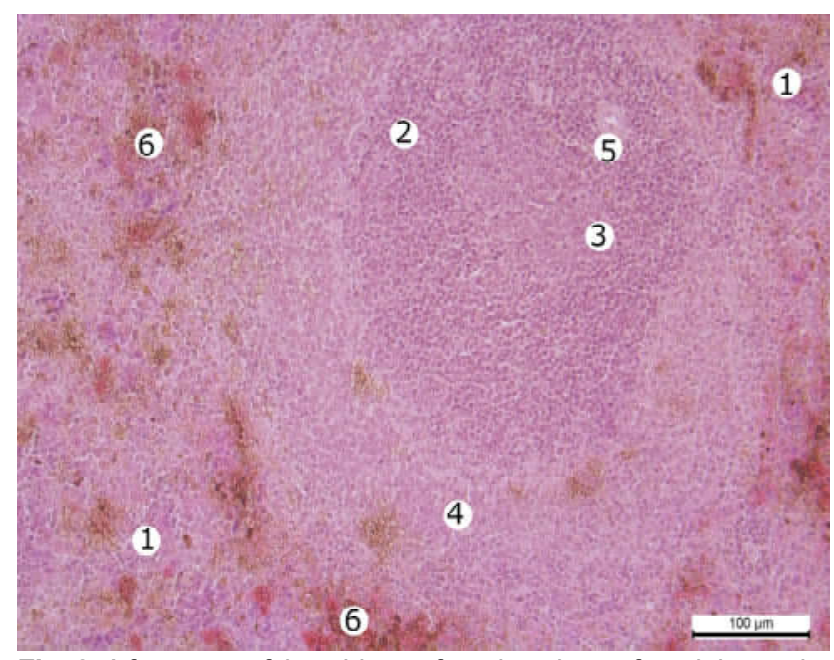

Fig. 2. A fragment of the white rat female spleen after eight weeks of HCD. Hematoxylin-eosin. Objective lens x20, eyepiece x10. 1 red pulp; 2 - white pulp, secondary lymph node 3 - center of reproduction of the lymph node; 4 - boundary zone; 5 - central artery; 6 - accumulation of hemosiderin and lipids in the venous sinuses of the red pulp.

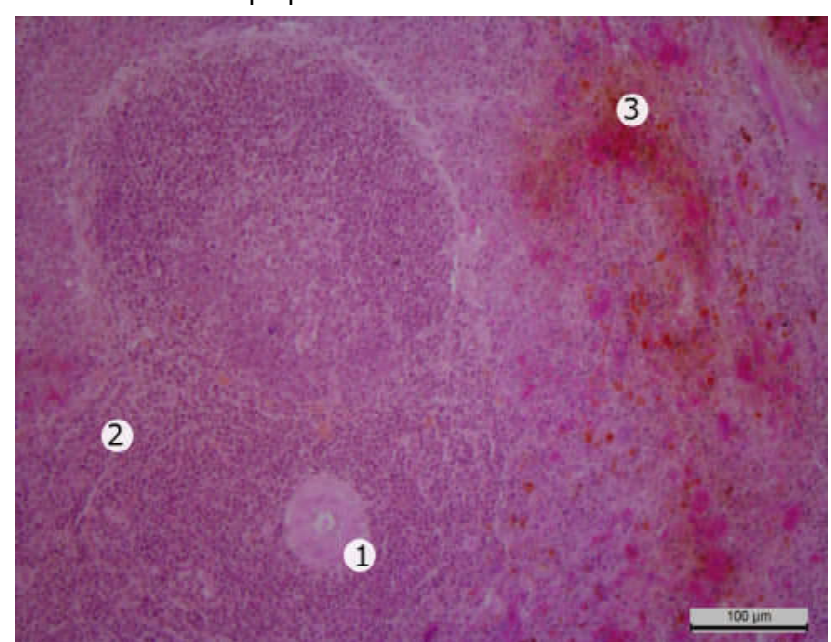

Fig. 3. A fragment of the spleen of a white rat female after two weeks of HCD cancellation. Hematoxylin-eosin. Objective lens x20, eyepiece $\times 10.1$ - central artery with a swollen wall and a narrowed lumen; 2 - white pulp, unclear border of mantle zone, 3 - accumulation of hemosiderin and lipids in venous sinuses of red pulp. parenchyma of white rats in males and females was almost unchanged from the previous group of animals and was $21.65 \pm 1.43 \%$ and $21.53 \pm 1.21 \%$. These figures are $16.0 \%$ and $18.4 \%$ lower the parameters of the intact group of animals (see Table 1). Accordingly, the relative area of the red pulp is $78.35 \pm 1.87 \%$ in male rats and up to $78.47 \pm 1.65 \%$ in female rats. These figures are $5.6 \%$ and $6.6 \%$ higher than the parameters of the intact group of animals (see Table 1).

Histological specimens show thickening of the central artery wall and narrowing of the lumen, which may be associated with edema (Fig. 3). Vascular edema is observed. Venous sinuses of red pulp are enlarged, containing hemosiderin and accumulation of lipids. Macrophages are filled with drops of hemosiderin.

4 weeks after abolition of HCD (4 group of animals), the relative area of white pulp in the spleen parenchyma of white rats of males and females decreased by $0.7 \%$ and $1.6 \%$ compared with the previous group of animals and is $21.51 \pm 1.09 \%$ and $21.19 \pm 0.69 \%$. These figures are $16.6 \%$ and $19.7 \%$ below the parameters of the intact group of animals (see Table 1). Accordingly, the relative area of the red pulp increases by $0.2 \%$ and $0.4 \%$ compared to the previous group of animals and is $78.49 \pm 1.56 \%$ in male rats and $78.81 \pm 1.23 \%$ in female rats. These figures are $5.8 \%$ and $7.0 \%$ higher than the parameters of the intact group of animals (see Table 1).

Six weeks after discontinuation of HCD (5 group of animals), the relative area of white pulp in the spleen parenchyma of white rats of males and females increased by $0.1 \%$ and $3.3 \%$ compared to the previous group of animals and is $21.53 \pm 1.03 \%$ and $21.88 \pm 0.98 \%$. These figures are $16.5 \%$ and $17.1 \%$ less than the parameters of the intact group of animals (see Table 1). Accordingly, the relative area of the red pulp decreases by $0.04 \%$ and $0.9 \%$ compared to the previous group of animals and is $78.47 \pm 1.34 \%$ in male rats and up to $78.12 \pm 1.76 \%$ in female rats. These figures are $5.7 \%$ and $6.1 \%$ higher than the parameters of the intact group of animals (see Table 1).

Eight weeks after abolition of HCD (6 group of animals), the relative area of white pulp in the spleen parenchyma of white rats in males and females is almost unchanged from 


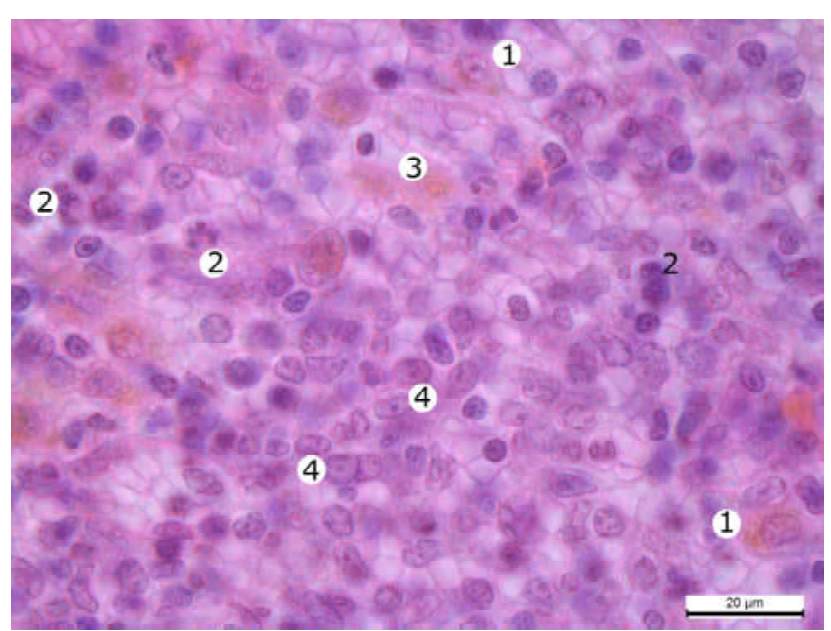

Fig. 4. A fragment of the spleen of a white rat female four weeks after abolition of HCD. Hematoxylin-eosin. Objective lens x100, eyepiece x10. 1 - macrophages with drops of hemosiderin in the cytoplasm; 2 - necrotic altered lymphocytes; 3 - drops of hemosiderin in the intercellular space of the red pulp; 4 lymphocytes.

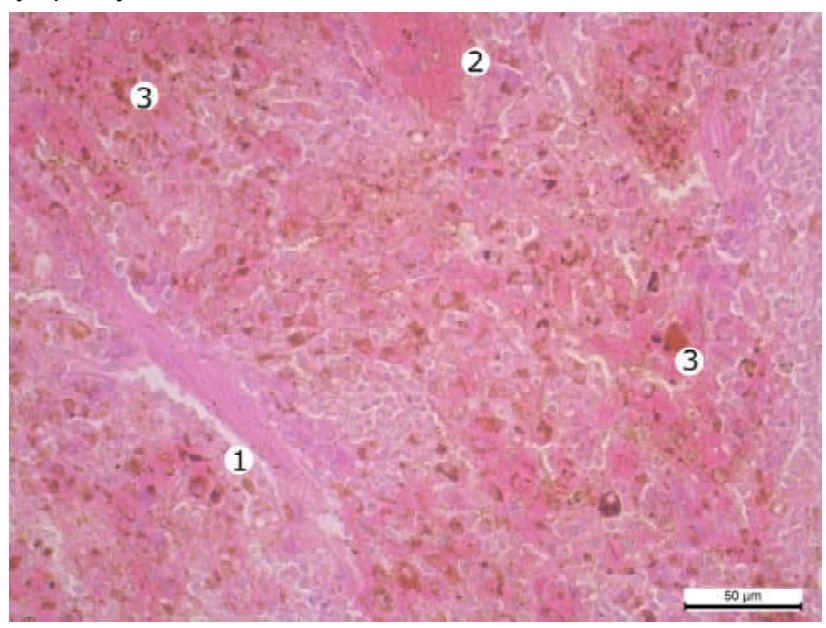

Fig. 5. A fragment of the red pulp of the white rat male spleen eight weeks after abolition of HCD. Hematoxylin-eosin. Objective lens $\mathrm{x} 40$, eyepiece $\times 10$. 1 - thickened and swollen Billroth cord; 2 adhesion of erythrocytes and platelets in the enlarged and fullblooded venous sinuses; 3 - accumulation of hemosiderin and lipids in the red pulp.

the previous group of animals and is $21.46 \pm 1.05 \%$ and $21.91 \pm 1.23 \%$. These figures are $16.8 \%$ and $16.9 \%$ less than the parameters of the intact group of animals (see Table 1). Accordingly, the relative area of red pulp is $78.54 \pm 1.54 \%$ in male rats and up to $78.09 \pm 1.43 \%$ in female rats. These figures are $5.8 \%$ and $6.1 \%$ higher than the parameters of the intact group of animals (see Table 1).

The depletion of lymphoid tissue with progression of mainly white pulp atrophy has been established. The area of the lymphoid nodules and the size of their centers of reproduction decreases, the boundaries between the nodules become not clear, differentiation into zones is not followed everywhere (Fig. 3). Billroth cords of red pulp thicken, become more tortuous. In the nuclei of cells, the phenomena of karyorrhexis and apoptosis are observed.

Therefore, no changes in the structure of the parenchyma of the spleen were detected in the 8-week abrogation of HCD.

\section{Discussion}

Similar structural changes, namely the enlargement and filling of the venous sinuses of the red pulp of the spleen were found in the spleen of rats with 30-day administration of Loratadine [7].

The authors describe that the administration to white rats of $\mathrm{SiO}_{2}$ nanoparticles, together with lead acetate, leads to hypoplasia of the white pulp of the spleen with a decrease in the T-lymphocytic zone, causes karyorrhexis and apoptosis of red pulp cells. There was also a sharp increase in the amount of iron-containing pigment, reflecting the process of erythrocyte death. In addition, the formation of diffuse small-focal lymphocyte clusters among the red pulp along the course of the vessels was revealed [3].

Intraperitoneal administration of extracts of mountain arnica and tormentil at a dose of $30 \mu \mathrm{l}$ per $20 \mathrm{~g}$ of mouse weight leads to a significant advantage of white pulp over red, lymphoid follicles have lost a distinct structure. Among the red pulp there are single megakaryocytes, and their number in the field of view of the microscope is higher, compared with the control samples [19].

The authors of studies showed that a high-nutrition diet reduced the expression of CD20, a surface molecule present on B-cells, which plays a large role in the immune response and produces IL-10 mainly in the spleen [13]. Moreover, splenocyte proliferation stimulated by T-cell and B-cell mitogens was significantly lower in obese individuals; thus, the functions of both T-cells and B-cells in the spleen can be impaired in obesity. The authors suggest that obesity-induced decrease in IL-10 synthesis in the spleen can lead to inflammatory reactions in the kidneys and metabolic disorders [13].

The authors describe that obesity reduces the size of inguinal lymph nodes, impairs lymphatic fluid transport and migration of dendritic cells to peripheral lymph nodes, and reduces the number of T-lymphocytes in lymph nodes. In general, obesity impairs the integrity of the immune system and leads to changes in the development of leukocytes, their migration and diversity [2].

Decreasing the population of "naive" T-cells (helpers) leads to a worsening of the immune system, which occurs with the onset of age. In animal model studies, obesity compromises the T-cell immune system due to increased adipogenesis in primary lymphoid organs and systemic inflammation. Due to the fact that obesity increases the risk of multiple age-related diseases, impaired immune competence is a possible mechanistic link between obesity and disease development in the elderly [24].

The prospects for further development are related to the further study of the morphometric and electron microscopic changes of the structural components of the 
rat spleen through different terms of experimental obesity and its correction.

\section{Conclusions}

1. After 8 weeks of HCD there is a significant decrease in the relative area of white pulp in the parenchyma of the spleen of white rats-males and females by $16.2 \%$ and $17.4 \%$, respectively, and an increase in the relative area of red pulp by $5.6 \%$ and $6.2 \%$.

2. At 8 weeks after HCD withdrawal, the relative area of white pulp in the spleen parenchyma of white male rats and females was $16.8 \%$ and $16.9 \%$ less than that of the intact animal group. Accordingly, the relative area of the red

\section{References}

[1]Alpert, M.A., Omran, J., \& Bostick, B.P. (2016). Effects of Obesity on Cardiovascular Hemodynamics, Cardiac Morphology, and Ventricular Function. Curr. Obes. Rep., 15, 156-171. doi: 10.1007/s13679-016-0235-6

[2]Andersen, C.J., Murphy, K.E., \& Fernandez, M.L. (2016). Impact of Obesity and Metabolic Syndrome on Immunity. Adv. Nutr., 7(1), 66-75. doi: 10.3945/an.115.010207

[3] Bandas, I.A., Kulitska, M.I., \& Korda, M.M. (2017). Structural changes of rat liver, kidney and spleen when exposed to silica nanoparticles and lead acetate. Bulletin of problems of biology and medicine, 1(135), 322-327.

[4] Buchan, L., Chaheyla, R., Fisher, A., Hellings, A., Castro, M., AlNakkash, L. ... Plochocki, J.H. (2018). High-fat, high-sugar diet induces splenomegaly that is ameliorated with exercise and genistein treatment. BMC Res Notes, 11, 752. doi: 10.1186/ s13104-018-3862-z

[5] Chien, M.Y., Ku, Yu.H., Chang, J.M., Yang, C.M., \& Chen, C.H. (2016). Effects of herbal mixture extracts on obesity in rats fed a high-fat diet. Journal of Food and Drug Analysis, 24(3), 594-601. doi: 10.1016/j.jfda.2016.01.012

[6] Coppey, L., Shevalye, H., Obrosov, A., Davidson, E., \& Yorek, M. (2018). Determination of peripheral neuropathy in high-fat diet fed low-dose streptozotocin-treated female C57BI/6J mice and Sprague-Dawley rats. J. Diabetes Investig., 9(5), 10331040. doi: $10.1111 /$ jdi. 12814

[7] Dudok, O.V. (2015). The state of the microstructure of the spleen under the conditions of application of Loratadine. World of medicine and biology, 2, 96-99.

[8] El-Aziza, R., Naguiba, M., \& Rashedb, L. (2018). Spleen size in patients with metabolic syndrome and its relation to metabolic and inflammatory parameters. The Egyptian Journal of Internal Medicine, 30, 78-82. doi: 10.4103/ejim.ejim_86_17

[9] Escobedo, N., \& Oliver, G. (2017). The Lymphatic Vasculature: Its Role in Adipose Metabolism and Obesity. Cell metabolism, 26(4), 598-609. doi: 10.1016/j.cmet.2017.07.020

[10] Esser, N., Legrand-Poels, S., Piette, J., Scheen, A.J., \& Paquot N. (2014). Inflammation as a link between obesity, metabolic syndrome and type 2 diabetes. Diabetes Research and Clinical Practice, 105(2), 141-150. doi: 10.1016/ j.diabres.2014.04.006

[11] Fedecostante, M., Spannella, F., Giulietti, F., Espinosa, E, DessiFulgheri, P., \& Sarzani, R. (2015). Associations between body mass index, ambulatory blood pressure findings, and changes in cardiac structure: relevance of pulse and nighttime pressures. J. Clin. Hypertens. (Greenwich), 17(2), 147-153. doi: $10.1111 /$ jch.12463 pulp is $5.8 \%$ and $6.1 \%$ higher than the parameters of the intact group of animals.

3. The depletion of lymphoid tissue with progression of mainly white pulp atrophy has been established. The area of the lymph nodes and the size of their reproductive centers decrease. Arteries with thickened wall, full-blooded, veins enlarged and full-blooded. Sinus red pulp dilated, hemosiderin and accumulation of lipids in the lumen of the venous sinuses. Macrophages are filled with drops of hemosiderin. In the conditions of 8-week cancellation of $\mathrm{HCD}$, no reverse changes in the structure of the parenchyma of the spleen were detected.

[12] Giles, E., Jackman, M., \& MacLean, P. (2016). Modeling DietInduced Obesity with Obesity-Prone Rats: Implications for Studies in Females. Front. Nutr., 3, 50-55. doi: 10.3389/ fnut.2016.00050

[13] Gotoh, K., Fujiwara, K., Anai, M., Okamoto, M., Masaki, T., Kakuma, T., \& Shibata, H. (2017). Role of spleen-derived IL-10 in prevention of systemic low grade inflammation by obesity. Endocr. J., 64, 375-378.

[14] Holmes, A., Coppey, L., Davidson, E., \& Yorek, M. (2015). Rat Models of Diet-Induced Obesity and High Fat/Low Dose Streptozotocin Type 2 Diabetes: Effect of Reversal of High Fat Diet Compared to Treatment with Enalapril or Menhaden Oil on Glucose Utilization and Neuropathic Endpoints. Journal of Diabetes Research, 2015, 60-68. doi: 10.1155/2015/ 307285.

[15] Inoue, H., Kodani, E., Atarashi, H., Okumura K., Yamashita, T., \& Origasa, H. (2016). Impact of Body Mass Index on the Prognosis of Japanese Patients with Non-Valvular Atrial Fibrillation. Am. J. Cardiol., 118(2), 215-221. doi: 10.1016/ j.amjcard.2016.04.036

[16] Jin, W., Cui, B., Li, P., Hua, F., Lv, X., Zhou, J., \& Zhang, X. (2018). 1,25-Dihydroxyvitamin D3 protects obese rats from metabolic syndrome via promoting regulatory $T$ cell-mediated resolution of inflammation. Acta Pharmaceutica Sinica B, 8(2), 178-187. doi: 10.1016/j.apsb.2018.01.001

[17] Kothari, V., Luo, Y., Tornabene, T., O'Neill, A.M., Greene, M.W., Geetha, T., \& Babu, J.R. (2017). High fat diet induces brain insulin resistance and cognitive impairment in mice. Biochim Biophys Acta., 1863(2), 499-508. doi: 10.1016/ j.bbadis.2016.10.006

[18] Oliveira, E., Castro, S., Ayupe, C.M., Ambrósio, G.E., Souza, P.V., Macedo, C.G., \& Ferreira, A.P. (2019). Obesity affects peripheral lymphoid organs immune response in murine asthma model. Immunology, 157(3), 268-279. doi: 10.1111/imm.13081

[19] Shemediuk, N.P., Zaitsev, O.O., \& Butsiak, V.I. (2010). Histological changes of the spleen, liver, kidneys of animals due to the action of bioactive complexes. Modern problems of toxicology, 2-3, 54-57.

[20] Song, Z., Xie, W., Chen, S., Strong, J.A.,, Print, M.S., Wang, J.I., ... Zhang, J.M. (2017). High-fat diet increases pain behaviors in rats with or without obesity, Sci. Rep., 7(1), 114. doi: 10.1038/s41598-017-10458-Z

[21] Wang, H.J., Si, Q.J., Shan, Z.L., Guo, Y.T., Lin, K., Zhao, X.N., \& Wang, Y.T. (2015). Effects of body mass index on risks for ischemic stroke, thromboembolism, and mortality in Chinese atrial fibrillation patients: a single-center experience. PLOS 
One, 10(4), 231-242. doi: 10.1371/journal.pone.0123516

[22] Wan, H., Wu, S., Wang, J., Yang, Y., Zhu, J., Shao, X. ... Zhang, H. (2017). Body mass index and the risk of all-cause mortality among patients with nonvalvular atrial fibrillation: a multicenter prospective observational study in China. Eur. J. Clin. Nutr., 71(4), 494-499. doi: 10.1038/ejcn.2016.183

[23] Yanagisawa, S., Inden, Y., Yoshida, N., Kato, H., Miyoshi-Fujii, A., Mizutani, Y., ... Murohara, T. (2016). Body mass index is associated with prognosis in Japanese elderly patients with atrial fibrillation: an observational study from the outpatient clinic. Heart Vessels, 31(9), 1553-1561. doi: 10.1007/s00380015-0765-y

[24] Yoshida, K., Nakashima, E., Kubo, Y., Yamaoka, M., Kajimura, J., Kyoizumi, S., ... Kusunoki, Y. (2014). Inverse Associations between Obesity Indicators and Thymic T-Cell Production Levels in Aging Atomic-Bomb Survivors. Survivors. PLoS One, 9(6), 98-101. doi: 10.1371/journal.pone.0091985

\section{СТРУКТУРНІ ЗМІНИ СЕЛЕЗІНКИ ПРИ ЕКСПЕРИМЕНТАЛЬНОМУ ОЖИРІНН \\ Гарапко T.B.}

В статті наведені та проаналізовані дані експериментального дослідження, яке проводилося на білих щурах самках та самиях репродуктивного віку. Ожиріння є однією з головних причин передчасної смерті у всьому світі. Метою дослідження було вивчення морфометричних та гістологічних змін паренхіми селезінки щурів при експериментальному ожирінні та після відміни висококалорійної дієти (ВКД). Дослідження проведено на 70 білих щурах репродуктивного віку (2,5-6,5 місяців) масою 120-280 е. Висококалорійна дієта досягалася завдяки тому, що в їжу додавали глутамат натрію в дозі 67 ме/ке маси тіла щура. Контролем слугували 10 білих щурів, які замість висококалорійної дієти отримували стандартний харчовий раціон віварію. Статистичну обробку цифрових даних проводили за допомогою програмного забезпечення "Ехсеl" та "STATISTICA 6.0" з використанням параметричних методів. Через 8 тижнів ВКД спостерігається достовірне зменшення відносної площі білої пульпи в паренхімі селезінки білих щурів самців та самок на 16,2\% та 17,4\%, та відповідно збільщення відносної площі червоної пульпи на 5,6\% та 6,2\%. Спостерігається імуноіндукуючий ефект з посиленою проліферацією активованих лімфоцитів та їх подальшим диференціюванням у плазматичні клітини. Через вісім тижнів після відміни ВКД відносна площа білої пульпи в паренхімі селезінки білих щурів самців та самок на 16,8\% та 16,9\% менше параметрів інтактної групи тварин. Відповідно відносна площа червоної пульпи на 5,8\% та 6,1\% перевищує параметри інтактної групи тварин. Площа лімфоїдних вузликів та розміри їх центрів розмноження зменшуються. В паренхімі органу зростає кількість моноцитів, макрофрагів та плазмоцитів. Залишки гемосидерину трапляються як в цитоплазмі макрофрагів, так і в міжклітинних просторах. Артерії з потовщеною стінкою, повнокровні, вени розширені та повнокровні. Венозні пазухи червоної пульпи розширені, містять залишки гемосидерину. Таким чином, встановлено виснаження лімсроїдної тканини з прогресуванням атрофої переважно білої пульпи. В умовах 8-тижневої відміни ВКД зворотних змін у структурі паренхіми селезінки не виявлено.

Ключові слова: ожиріння, щур, селезінка, біла пульпа, червона пульпа.

\section{СТРУКТУРНЫЕ ИЗМЕНЕНИЯ СЕЛЕЗЕНКИ ПРИ ЭКСПЕРИМЕНТАЛЬНОМ ОЖИРЕНИИ \\ Гарапко T.B.}

В статье приведены и проанализированы данные экспериментального исследования, которое проводили на белых крысах самках и самцах репродуктивного возраста. Ожирение является одной из главных причин преждевременной смерти во всем мире. Целью исследования было изучение морфометрических и гистологических изменений паренхимы селезенки крыс при экспериментальном ожирении и после отмены высококалорийной диеты (ВКД). Исследование проведено на 70 белых крысах репродуктивного возраста (2,5-6,5 месяцев) массой 120-280 г. Высококалорийная диета достигалась благодаря тому, что в пищу добавляли глутамат натрия в дозе 67 мг/кә массы тела крысы. Контролем служили 10 белых крыс, которые вместо высококалорийной диеты получали стандартный пищевой рацион вивария. Статистическую обработку цифровых данных проводили с помощью программного обеспечения "Excel" и "STATISTICA 6.0" с использованием параметрических методов. Через 8 недель ВКД наблюдается достоверное уменьшение относительной площади белой пульпы в паренхиме селезенки белых крыс самцов и самок на 16,2\% и 17,4\%, и, соответственно, увеличение относительной площади красной пульпы на 5,6\% и 6,2\%. Наблюдается иммуноиндуцирующий эффект с усиленной пролиферацией активированных лимфоцитов и их последующим дифрференцированием в плазматические клетки. Через 8 недель после отмены ВКД относительная площадь белой пульпы в паренхиме селезенки белых крыс самцов и самок на 16,8\% и 16,9\% меньше параметров интактной группы животных. Соответственно, относительная площадь красной пульпы на 5,8\% и 6,1\% превышает параметры интактной группы животных. Площадь лимфоидных узелков и размеры их центров размножения уменьшаются. В паренхиме органа растет количество моноцитов, макрофагов и плазмоцитов. Остатки гемосидерина случаются как в цитоплазме макрофрагов, так и в межклеточных пространствах. Артерии с утолщенной стенкой, полнокровные, вены расширены и полнокровные. Венозные пазухи красной пульпы расширены, содержат остатки гемосидерина. Таким образом, установлено истощение лимфроидной ткани с прогрессированием атрофрии преимущественно белой пульпы. В условиях 8-недельной отмены ВКД обратных изменений в структуре паренхимы селезенки не обнаружено. Ключевые слова: ожирение, крыса, селезенка, белая пульпа, красная пульпа. 